\title{
EDITORIAL
}

\section{YEARS OF CONTEMPORARY MILITARY CHALLENGES}

Reading the title of this editorial, many might think that Contemporary Military Challenges have not been published for so many years, and that before there was another publication, entitled Bulletin of the Slovenian Armed Forces. In a way, this is, of course, true. Nevertheless, this year indeed marks 20 years since the General Staff of the Slovenian Armed Forces began to publish its own publication, at the time called the Bulletin of the Slovenian Armed Forces. Its purpose was to inform the internal and external public about the novelties in the fields of security, defence and the military or better armed forces.

Normally, in NATO and EU member states, professional and scientific defencerelated works are published by ministries of defence, or research institutes within the ministries, which issue publications on defence-strategy related topics. General Staffs, however, publish their own publications, which are typically intended for military professionals. Educational organizational units usually issue publications intended for the publication of graduation thesis of students at various levels of military education, while military museums or related units are responsible for the development of topics relating to military history. Following this concept, the publication Vojstvo (Armed Forces) was published between 1996 and 2000 by the Ministry of Defence of the Republic of Slovenia.

The General Staff of the Slovenian Armed Forces first published the Bulletin of the Slovenian Armed Forces in 1999. The date written in the first issue is September 1999; however, according to the co-workers who contributed to this success, the first issue was in fact printed in November 1999.

In addition to the Contemporary Military Challenges, two other periodicals are being published in the Slovenian Armed Forces, namely, Vojaškošolski zbornik (Military Schools Bulletin), issued by the Military Schools Centre, and Vojaška zgodovina (Military History) issued by the Military Museum, which also forms a part of the Military School Centre. 
The gap, which occurred after Vojstvo was no longer published, was filled by the Bulletin of the Slovenian Armed Forces, later the Contemporary Military Challenges, which publishes scientific and professional articles by Slovenian and foreign authors. The name of the publication was changed upon the advice of Editorial Board members on the grounds that the name "bulletin" did not reflect the contents or the subject field of the publication. In the dictionary of standard Slovene, the Slovene equivalent for "bulletin" is defined as a short official message to the public, a note, an informative periodical or newsletter.

Consequently, the editorial board undertook the demanding task of finding a new name for the publication and found the name Contemporary Military Challenges.

Much work and effort have been invested in the production of a military publication. The majority of those who contributed to this effort were engaged primarily on their own initiative, in private time. Writing articles according to international standards requires order, effort and discipline. Many gave up before they even started to write and, the authors who have written articles for this military publication have, in most cases, departed from the average further down their careers.

The authors have been numerous. Sixty people have been members of the editorial board between the beginning of the publication and the end of 2018. Since 2008, when peer review was introduced, 279 authors have contributed their articles, many of them repeatedly. The one especially standing out is a Slovenian Armed Forces Major who has written 10 articles. The list of all referees includes 103 names. The referee who has contributed the largest number of reviews is a Brigadier General with 54 reviews. There are also 18 referees who have contributed more than ten reviews.

\begin{tabular}{|l|l|l|l|l|}
\hline Year & No. of articles & $\begin{array}{l}\text { Scientific } \\
\text { articles }\end{array}$ & $\begin{array}{l}\text { Professional } \\
\text { articles }\end{array}$ & Editorial \\
\hline 2017 & 24 & $21(87.5 \%)$ & $3(12.5 \%)$ & 5 \\
\hline 2016 & 25 & $18(72 \%)$ & $7(28 \%)$ & 5 \\
\hline 2015 & 21 & $10(48 \%)$ & $11(52 \%)$ & 4 \\
\hline 2014 & 25 & $16(64 \%)$ & $9(36 \%)$ & 4 \\
\hline 2013 & 24 & $12(50 \%)$ & $12(50 \%)$ & 10 \\
\hline 2012 & 26 & $11(44 \%)$ & $14(56 \%)$ & 4 \\
\hline 2011 & 31 & $17(54 \%)$ & $14(45 \%)$ & 4 \\
\hline 2010 & 45 & $17(37 \%)$ & $28(62 \%)$ & 4 \\
\hline 2009 & 42 & $18(43 \%)$ & $24(57 \%)$ & 7 \\
\hline
\end{tabular}


The long years of effort have yielded results and resulted in a fact that, in 2010, the Slovenian Armed Forces publication was indexed in the PAIS International database within Proquest. Consequently, it was included in the list of the journals of the Slovenian Research Agency. For the publication of articles in the Contemporary Military Challenges, the authors are therefore granted 30 academic points.

The quality of the contents will certainly be preserved in the future, since the editorial board and the editorial council provide a wide range of authors from various fields, institutions and countries.

On the $20^{\text {th }}$ anniversary of the publication, appreciation goes to every single person who has contributed to the fact that, even when everything did not run smoothly, the publication kept going and was regularly published. There have been and still are individuals who have contributed more, better and with more motivation, but everyone deserves credit for the success of the publication.

In this last issue of the jubilee year, the authors devoted themselves to very topical subjects.

In his article Reduction of risks for the development of civil-military conflicts Branimir Furlan highlights the need for military leadership to recognise the prevailing role of civilian leadership in debates, which give rise to disagreements, and the need for a prudent use of civilian control mechanisms by the bodies exercising control. Does that sound familiar?

In his article Defining concepts in the case of a military strategy Pavel Vuk writes about the theories, strategies and concepts. He derives his findings from Sartori's method of concept analysis and Goertz's method of attaching or removing adjectives to and from a concept. He claims that military strategy is a concept and that concepts are the cornerstones of theory. What does this mean in practice when the properties of concepts must be measurable?

There is no generally accepted definition of a robot and definitions of a military robot are often unclear, say Anja Kolak and Franc Mali in their article (Military) Robot systems: criteria for classification and social and ethical dilemmas. They propose starting points for the creation of a new definition of a (military) robot system and highlight other dilemmas that are generated by the development and use of autonomous robot systems.

Marjan Sirk notes that the communication strategy and its proper implementation can make a decisive contribution to the realization of national goals, and, using effective strategic communications, the state can also work to the benefit of its armed forces and make a decisive contribution to the country's security. Under the title Strategic communications as an element of state power the author draws 
conclusions on the situation in the country in this regard and suggests options for possible improvements in order to meet international standards.

Introducing a hybrid threat identification model is the title of the article by David Stonič. He says that hybrid threats do not know borders and do not distinguish between military and civilian. This is also the reason why research and search for solutions to identify and prevent hybrid threats cannot just be the responsibility of military organizations, but rather, as the author believes, all those who in any way constitute a part of the national security system.

With this issue, we conclude the $20^{\text {th }}$ anniversary of the publication issued by the General Staff of the Slovenian Armed Forces. We wish you pleasant reading and a number of ideas for new articles! 